\title{
Isolation and characterization of a new Methanoculleus bourgensis strain KOR-2 from the rumen of Holstein steers
}

\author{
Urantulkhuur Battumur ${ }^{1,2}$, Manhee Lee ${ }^{3}$, Gui Sek Bae ${ }^{4}$, and Chang-Hyun Kim ${ }^{5, *}$
}

* Corresponding Author: Chang-Hyun Kim Tel: +82-31-670-5095, Fax: +82-31-670-5099,

E-mail: kimch@hknu.ac.kr

${ }^{1}$ Graduate School of Future Convergence, Hankyong National University, Anseong 17579, Korea

2 School of Animal Science and Biotechnology, Mongolian University of Life Sciences, Ulaanbaatar 17024, Mongolia

${ }^{3}$ Department of Animal Life and Environment Science, General Graduate School, Hankyong National University, Anseong 17579, Korea

${ }^{4}$ Department of Animal Science and Technology, Chung-Ang University, Anseong 17546, Korea

${ }^{5}$ Department of Animal Life and Environment Science, Hankyong National University, Anseong 17579, Korea

ORCID

Chang-Hyun Kim

https://orcid.org/0000-0001-6325-9755

Submitted May 30, 2018; Revised Jun 29, 2018; Accepted Jul 6, 2018
Objective: To isolate and identify new methanogens from the rumen of Holstein steers in Korea.

Methods: Representative rumen contents were obtained from three ruminally cannulated Holstein steers $(793 \pm 8 \mathrm{~kg})$. Pre-reduced media were used for the growth and isolation of methanogens. Optimum growth temperature, $\mathrm{pH}$, and sodium chloride $(\mathrm{NaCl})$ concentration as well as substrate utilization and antibiotic tolerance were investigated to determine the physiological characteristics of the isolated strain. Furthermore, the isolate was microscopically studied for its morphology. Polymerase chain reaction of $16 \mathrm{~S}$ rRNA and $m c r A$ gene-based amplicons was used for identification.

Results: One strain designated as KOR-2 was isolated and found to be a non-motile irregular coccus with a diameter of 0.2 to $0.5 \mu \mathrm{m}$. KOR-2 utilized $\mathrm{H}_{2}+\mathrm{CO}_{2}$ and formate but was unable to metabolize acetate, methanol, trimethylamine, 2-propanol, and isobutanol for growth and methane production. The optimum temperature and $\mathrm{pH}$ for the growth of $\mathrm{KOR}-2$ were $38^{\circ} \mathrm{C}$ and 6.8 to 7.0, respectively, while the optimum $\mathrm{NaCl}$ concentration essential for KOR-2 growth was $1.0 \%(\mathrm{w} / \mathrm{v})$. KOR-2 tolerated ampicillin, penicillin G, kanamycin, spectromycin, and tetracycline. In contrast, the cell growth was inhibited by chloramphenicol. Phylogenetic analysis of 16S rRNA and mcrA genes revealed the relatedness between KOR-2 and Methanoculleus bourgensis.

Conclusion: Based on the physiological and phylogenetic characteristics, KOR-2 was thought to be a new strain within the genus Methanoculleus and named Methanoculleus bourgensis KOR-2.

Keywords: Methanogen; Rumen; $16 \mathrm{~S}$ rRNA; mcrA; Methanoculleus bourgensis

\section{INTRODUCTION}

In the past decade, ruminal methanogens have attracted much research interest to mitigate ruminal methane $\left(\mathrm{CH}_{4}\right)$ emission, as rumen $\mathrm{CH}_{4}$ emission accounts for about $17 \%$ of the global $\mathrm{CH}_{4}$ emission [1]. In addition, about $2 \%$ to $12 \%$ of the ingested feed energy is lost in the form of $\mathrm{CH}_{4}$ [2]. Studies related to ruminal methanogens are directed to understand their diversity and community structure, relationship with other ruminal microbes and feed efficiency, $\mathrm{CH}_{4}$ emission, and responses to dietary interventions.

The rumen provides a unique environment characterized by a relatively rapid passage rate and readily available carbon dioxide $\left(\mathrm{CO}_{2}\right)$ and hydrogen $\left(\mathrm{H}_{2}\right)$. This environment, therefore, facilitates the assembly of a community of archaea and is different from other anoxic habitats. Methanogens are the most dominant archaea in the rumen, and most of them are hydrogenotrophic rather than acetoclastic in spite of the high concentrations of acetates in the rumen [3]. $\mathrm{H}_{2}$ and $\mathrm{CO}_{2}$ produced from the fermentative pathways of other ruminal microbes are scavenged by rumen methanogens that also utilize formic acid and methyl-amines as sub- 
strates [4]. The interspecies $\mathrm{H}_{2}$ transfer in the rumen ecosystem prevents $\mathrm{H}_{2}$ accumulation and feedback inhibition. Most methanogens live freely in the rumen fluid or as members of the biofilm adhering to feed particles, whereas small portions of the ruminal methanogens are symbionts and may be either ectosymbionts or endosymbionts [5].

Given that methanogens are difficult to study through culture-based methods, many researchers have instead used culture-independent techniques such as real-time polymerase chain reaction (qPCR), denaturing gradient gel electrophoresis, and sequencing approaches, all of which have been valuable tools for the study of the biodiversity of complex microbial communities such as those in the rumen [6,7]. The diversity in the rumen methanogens is much smaller than that of rumen bacteria, and methanogens account for only $6.8 \%$ of total ruminal small subunit ribosomal ribonucleic acid (SSU rRNA) [8]. Archaea represent $<3.3 \%$ of the total rRNA (both $16 \mathrm{~S}$ and $18 \mathrm{~S})$ in the rumen [3]. The $16 \mathrm{~S}$ rRNA gene sequences from cultured methanogens only account for approximately $0.7 \%$ of the total archaeal sequences of rumen origin, and several taxa have no single cultured representative [3]. In comparison with other anaerobic habitats from where methanogens have been isolated and classified into 28 genera and more than 100 species [9], the diversity and species richness of ruminal methanogens are quite low, reflecting the highly selective ruminal environment for methanogens [10]. To date, only 10 species of ruminal methanogens have been isolated as pure cultures $[11,12]$. Methanobacterium formicicum, Methanobacterium bryantii, Methanobrevibacter ruminantium, Methanobrevibacter millerae, Methanobrevibacter olleyae, Methanomicrobium mobile, Methanoculleus olentangyi (a later heterotypic synonym of M. bourgensis), Methanosarcina barkery, Methanobrevibacter boviskoreani, Methanobacterium beijingense, M. marisnigri, and Methanosarcina mazei (based on the RDP database). Here, we have isolated and studied the characteristics of a strain of $M$. bourgensis from the rumen of Holstein steers in Korea.

\section{MATERIALS AND METHODS}

This study was approved by the Institutional Animal Care and Use Committee at the Chung-Ang University, Seoul, Korea (No. 2013-0047).

\section{Source of inoculum}

Representative rumen contents were obtained from three ruminally cannulated Holstein steers $(793 \pm 8 \mathrm{~kg}) 2 \mathrm{~h}$ after morning feeding. Holstein steers were offered typified commercial concentrates (Table 1) and rice straw at a ratio of 40:60. The steers had a free access to the diet and water. Fresh rumen contents $(900 \mathrm{~mL})$ were collected into bottles previously kept warm and filled with $\mathrm{O}_{2}$ free- $\mathrm{CO}_{2}$ gas and then filtered through four
Table 1. Composition of the concentrate mix

\begin{tabular}{lc}
\hline Items & \\
\hline Ingredients & g/kg of dry matter \\
Ground corn & 30.2 \\
Wheat & 21.0 \\
Soybean meal & 24.0 \\
Rice bran & 10.0 \\
Tapioca & 178.0 \\
Sesame oil meal & 14.0 \\
Palm kernel meal & 410.8 \\
DDGS & 220.0 \\
Molasses & 50.0 \\
Condensed molasses soluble & 10.0 \\
Salt & 3.0 \\
Limestone & 20.0 \\
CaCO & \\
Minerals and vitamin mixture ${ }^{1)}$ & 7.0 \\
Chemical composition & 7.0 \\
Dry matter & \\
Crude protein & 882.7 \\
Ether extract & 145.0 \\
Crude fiber & 67.7 \\
Undegradable protein & 126.8 \\
Ash & 73.6 \\
NFE & 74.9 \\
NFC & 471.0 \\
ADF & 198.3 \\
NDF & 230.8 \\
TDN & 396.9 \\
\hline (n) & 710.2 \\
\hline
\end{tabular}

DDGS, dried distillers grain with solubles; NFE, nitrogen-free extract; NFC, non-fiber carbohydrate; ADF, acid detergent fiber; NDF, neutral detergent fiber; TDN, total digestible nutrients.

1) Minerals and vitamin mixture: vitamin $A, 28,000 \mathrm{IU}$; vitamin $\mathrm{D}_{3}, 4,000 \mathrm{IU}$; vita$\min \mathrm{E}, 80 \mathrm{IU} ; \mathrm{Mn}, 80$ ppm; Zn, 100 ppm; Fe, 70 ppm; Cu, 50 ppm; Co, 0.5 ppm; I, 2.0 ppm; Se, 1.0 ppm.

layers of gauze. The filtered rumen fluid was used as an inoculum to isolate methanogens. The concentrates were oven-dried at $60^{\circ} \mathrm{C}$ for 3 days, milled to pass through a 1-mm sieve, and analyzed for chemical composition using the appropriate AOAC [13] and Van Soest method [14].

\section{Medium}

Methanogens are extremely sensitive to oxygen and need strict anoxic conditions; therefore, pre-reduced media are essential for their growth and isolation [6,7]. The methods used for the preparation of media and substrate solutions and culture techniques were those described by Hungate [15], as modified by Balch et al [16]. For enrichment culture and isolation, the medium was prepared based on the modification by Sowers and Schreier [17] and contained the following compounds (per liter distilled water): $\mathrm{KH}_{2} \mathrm{PO}_{4}, 0.51 \mathrm{~g} ; \mathrm{K}_{2} \mathrm{HPO}_{4}$, $0.24 \mathrm{~g} ; \mathrm{MgSO}_{4} \cdot 7 \mathrm{H}_{2} \mathrm{O}, 0.204 \mathrm{~g} ;\left(\mathrm{NH}_{4}\right)_{2} \mathrm{SO}_{4}, 0.255 \mathrm{~g} ; \mathrm{NaCl}, 1.02$ g; $\mathrm{CaCl}_{2} \cdot 2 \mathrm{H}_{2} \mathrm{O}, 0.134 \mathrm{~g}$; vitamin solution, $10.0 \mathrm{~mL}$; yeast extract, $1.0 \mathrm{~g}$; sodium acetate, $50 \mathrm{mM}$; methanol, $50 \mathrm{mM}$; sodium 
formate, $50 \mathrm{mM}$; rumen fluid, $300 \mathrm{~mL}$; $\mathrm{NaHCO}_{3}, 5.0$ g; resazurin, $0.001 \mathrm{~g} ; 0.2 \mathrm{M}$ cysteine hydrochloride, $15 \mathrm{~mL}$; and 0.2 $\mathrm{M} \mathrm{Na}_{2} \mathrm{~S} \cdot 9 \mathrm{H}_{2} \mathrm{O}, 4.0 \mathrm{~mL}$. Clarified rumen fluid was prepared by filtering the rumen fluid collected from the rumen of Holstein steers, followed by centrifugation at $13,000 \times g$ for $30 \mathrm{~min}$. The rumen fluids were autoclaved at $121^{\circ} \mathrm{C}$ for $20 \mathrm{~min}$ and recentrifuged to obtain a clear yellow solution. The yellow solution $(5 \%, \mathrm{v} / \mathrm{v})$ was used to supply unknown growth factors. The medium was prepared under a $\mathrm{H}_{2} / \mathrm{CO}_{2}(80: 20, \mathrm{v} / \mathrm{v})$ gas phase at $173 \mathrm{kPa}(25 \mathrm{psi})$ and its $\mathrm{pH}$ was adjusted between 6.8 and 7.0. The medium was sterilized by autoclaving at $121^{\circ} \mathrm{C}$ for $30 \mathrm{~min}$.

\section{Enrichment and isolation}

Enrichments were performed in the medium with $\mathrm{pH} 7.0$ adjusted under $\mathrm{H}_{2} / \mathrm{CO}_{2}(80: 20$, v/v) gas phase. A 5-mL inoculum was added to vials containing medium $(45 \mathrm{~mL})$. To inhibit the growth of bacteria, streptomycin sulfate $\left(7 \times 10^{4} \mathrm{IU} / \mathrm{L}\right)$ and benzyl penicillin $\left(2 \times 10^{10} \mathrm{IU} / \mathrm{L}\right)$ were added to the medium. The inoculated medium was incubated at $38^{\circ} \mathrm{C}$ in the dark for 2 weeks. After detection of high levels of methane in the culture, $5 \mathrm{~mL}$ of the culture was anaerobically transferred into a new vial of sterile medium. Roll tubes containing the medium with $1.8 \%$ agar were prepared, followed by four successive transfers. Well-isolated colonies were withdrawn with Pasteur pipettes and transferred to culture tubes containing the medium under anaerobic condition. The culture tubes were sealed with butylrubber stoppers and repressurized with sterile filtered $\mathrm{H}_{2} / \mathrm{CO}_{2}$ $(80: 20, \mathrm{v} / \mathrm{v})$ at $173 \mathrm{kPa}(25 \mathrm{psi})$. The organism was re-isolated with the solid medium from the liquid cultures and inoculated on the bacterial growth medium to check for the purity of methanogen cultures. The bacterial growth medium contained peptone $(2.5 \mathrm{~g} / \mathrm{L})$, yeast extract $(2.5 \mathrm{~g} / \mathrm{L})$, d-glucose $(0.5 \mathrm{~g} / \mathrm{L})$, d-cellobiose $(0.5 \mathrm{~g} / \mathrm{L})$, and d-xylose $(0.5 \mathrm{~g} / \mathrm{L})$. An antibiotic mixture containing four antibiotics (benzyl penicillin, $0.5 \mathrm{mg} / \mathrm{mL}$; streptomycin sulfate, $0.5 \mathrm{mg} / \mathrm{mL}$; vancomycin$\mathrm{HCl}, 0.2 \mathrm{mg} / \mathrm{mL}$; and ampicillin, $0.2 \mathrm{mg} / \mathrm{mL}$ ) was prepared for the further purification of the isolated strain KOR-2. After purification, the isolate was incubated in the media without antibiotics.

\section{Physiological studies}

Optimum growth temperature, $\mathrm{pH}$, and $\mathrm{NaCl}$ concentration as well as substrate utilization and antibiotic tolerance were investigated to determine the physiological characteristics of the KOR-2 strain. Growth was confirmed by observing optical density (OD) at $660 \mathrm{~nm}\left(\mathrm{OD}_{660}\right)$ with a spectrophotometer (V-530, Jasco, Tokyo, Japan) and measuring the methane concentration in the gas phase using a gas chromatograph (GC-2010A, Shimadzu, Kyoto, Japan). All experiments for physiological studies were repeated twice.

The medium without acetate, formate, and methanol was prepared under $\mathrm{N}_{2}$ and used for substrate utilization studies. Anaerobic stocks of the filter-sterilized substrates (sodium formate, sodium acetate, trimethylamine, methanol, 2-propanol, and isobutanol) were prepared and separately added at a final concentration of $50 \mathrm{mM}$. Freshly grown cultures of the isolate were inoculated at $10 \%(\mathrm{v} / \mathrm{v})$ and vials were incubated at $38^{\circ} \mathrm{C}$ for 20 days. The medium under $\mathrm{H}_{2} / \mathrm{CO}_{2}$ served as the control.

The optimum growth temperature in the medium was determined at optimum $\mathrm{pH}$. Vials inoculated with $10 \%(\mathrm{v} / \mathrm{v})$ culture were incubated at temperatures ranging from $20^{\circ} \mathrm{C}$ to $50^{\circ} \mathrm{C}$. The vials were pressurized every other day with $\mathrm{H}_{2} / \mathrm{CO}_{2}$ to ensure an adequate supply of substrate.

The optimum growth $\mathrm{pH}$ in the medium was determined at the optimum temperature, with $\mathrm{pH}$ values ranging from 4.0 to 9.0. Media with $\mathrm{pH}$ above 4.0 were prepared by adding sterile sodium carbonate $\left(\mathrm{Na}_{2} \mathrm{CO}_{3}\right)$ to media at $\mathrm{pH} 4.0$ until the required $\mathrm{pH}$ value was reached. Medium with $\mathrm{pH} 4.0$ was produced by removing sodium bicarbonate $\left(\mathrm{NaHCO}_{3}\right)$ from the medium and cooling it under a $\mathrm{CO}_{2}$ headspace.

The sensitivity of KOR-2 strain to ampicillin, penicillin G, spectromycin, kanamycin, tetracycline, and chloramphenicol (all at a concentration of $100 \mu \mathrm{g} / \mathrm{mL}$ ) was tested. Aliquots (5 $\mathrm{mL}$ ) of the cultures were inoculated into fresh media containing one of the six antibiotics. KOR-2 strain was incubated for 1 week at $38^{\circ} \mathrm{C}$. The tolerance to antibiotics was determined by comparing the growth of cultures containing these antibiotics to that of the control.

The salinity range of the isolate was tested at $\mathrm{NaCl}$ concentrations ranging from $0.5 \%$ to $3.0 \%$ at an interval of $0.5 \%$. Media with various concentrations of $\mathrm{NaCl}$ were prepared by adding a sterile anoxic stock solution of $58.44 \mathrm{~g} / \mathrm{L} \mathrm{NaCl}$.

\section{Microscopy}

An Olympus BX41 phase-contrast microscope (Olympus, Tokyo, Japan) was routinely used to observe cells. Motility was determined by the hanging-drop method using a glass cavity slide.

\section{DNA extraction and $\mathrm{G}+\mathrm{C}$ content}

Culture samples of KOR-2 strain grown in the media were used for DNA isolation (FastDNA SPIN kit for soil, MP Biomedicals, Irvine, CA, USA) following the manufacturer's instructions. DNA integrity was evaluated on $1 \%$ agarose gels and DNA concentration was determined using a Nanodrop (ND 2000, Thermo Fisher Scientific, Waltham, MA, USA). The DNA G+C content was analyzed from thermal denaturation profiles [18]. The experiments for DNA extraction and $\mathrm{G}+\mathrm{C}$ content of KOR-2 strain were conducted several times until clear results were obtained.

Polymerase chain reaction amplification of $16 \mathrm{~S}$ rRNA 
genes

The primer pair Ar109f (5'-ACKGCTCAGTAACACGT-3') [19] and Ar1383r (5'-CGGTGTGTGCAAGGAGCA-3') [20] was used to obtain $16 \mathrm{~S}$ rRNA gene amplicons $(\sim 1,350 \mathrm{bp})$. Reaction mixtures contained the following components in a final volume of $20 \mu \mathrm{L}$ within a $200-\mu \mathrm{L}$ PCR tube: $2 \mu \mathrm{L}$ of PCR buffer (Takara, Tokyo, Japan), $2 \mu \mathrm{L}$ of dNTP mix (35 mM), $0.5 \mu \mathrm{L}$ of each primer $(10 \mathrm{pmol} / \mu \mathrm{L}), 0.1 \mu \mathrm{L}$ of Taq DNA polymerase (Takara, Japan), $1.0 \mu \mathrm{L}$ of template DNA sample (100 ng), and $13.9 \mu \mathrm{L}$ of molecular grade water (Severn Biotech Ltd, Kidderminster, Worcester, UK). PCR was started by immediately placing the reaction tubes into a preheated $\left(94^{\circ} \mathrm{C}\right)$ thermal cycler (PCR Thermal Cycler Dice, Takara, Japan). The thermal program was as follows: Initial denaturation step $\left(94^{\circ} \mathrm{C}, 4 \mathrm{~min}\right)$ followed by 30 cycles of denaturation $\left(94^{\circ} \mathrm{C}, 30 \mathrm{~s}\right)$, annealing $\left(55^{\circ} \mathrm{C}, 30 \mathrm{~s}\right)$, and extension $\left(72^{\circ} \mathrm{C}, 90 \mathrm{~s}\right)$. After a final extension step $\left(72^{\circ} \mathrm{C}, 6 \mathrm{~min}\right)$, samples were stored at $4^{\circ} \mathrm{C}$ until further analysis. Each PCR run included a positive control of DNA extracted from pure cultures and a negative PCR control where molecular grade water was substituted for the DNA template. The DNA product was analyzed using gel electrophoresis $(1.2 \% \mathrm{w} / \mathrm{v}$ agarose gel stained and run at $100 \mathrm{~V}$ for $30 \mathrm{~min}$ in $1 \times$ tris-acetate ethylene-diamine-tetraacetic acid [EDTA; TAE] buffer with $5 \mu \mathrm{L}$ aliquots of each DNA product). TAE buffer comprised $40 \mathrm{mM}$ Tris base, $20 \mathrm{mM}$ acetic acid, and $0.5 \mathrm{M}$ EDTA (pH 8.0). The gel was run with $2.5 \mu \mathrm{L}$ of Ladder I DNA quantification marker (TNT research, Seoul, Korea) and imaged using the Bio Imaging System (Daihan, Seoul, Korea). Photographs were obtained using Wise Capture II software (Daihan, Korea).

Polymerase chain reaction amplification of $m c r A$ genes The $m c r A$ gene fragments were amplified using the primer combinations MLf (5'-GGTGGTGTMGGATTC ACACARTA YGCWACAGC-3') and MLr (5'-TTCATTGCRTAGTTWGG RTAGTT-3'), yielding 490-bp amplicons [21]; ME1 (5'-GCM ATGCARATHGGWATGTC- ${ }^{\prime}$ ) and ME2 (5'-TCATKGCRTA GTTDGGRTAGT-3'), yielding 740-bp amplicons [22]; and MR1 (5'-GACCTCCACTWCGT VAACAACGC-3') and ME2, yielding amplicons of $\sim 1,100 \mathrm{bp}$ [23]. Denaturation, annealing, and extension were carried out at $96^{\circ} \mathrm{C}(15 \mathrm{~s}), 55^{\circ} \mathrm{C}(30 \mathrm{~s})$, and $72^{\circ} \mathrm{C}(90 \mathrm{~s})$, respectively, with MLf/MLr primers, and $94^{\circ} \mathrm{C}$ (40 s), $50^{\circ} \mathrm{C}(45 \mathrm{~s})$, and $72^{\circ} \mathrm{C}(90 \mathrm{~s})$, respectively, with ME1/ME2 and MR1/ME2 primers.

\section{Phylogenetic and sequencing analyses}

Purification of PCR products was performed with the AccuPrep PCR purification kit (Bioneer, Daejeon, Korea). PCR products were sequenced using the BigDye terminator cycle sequencing kit on ABI 3730XL capillary DNA Sequencer (Applied Biosystems, Thermo Fisher Scientific Inc., Carlsbad, CA, USA). $16 \mathrm{~S}$ rRNA and $m c r A$ gene sequences from the isolated strain were compared to the similar sequences obtained from GenBank using the BLAST program. Phylogenetic analysis was conducted using MEGA 4.0 [24]. We examined eight additional 16S rRNA sequences (M. bourgensis MS2 [HE964772], M. palmolei [Y16382], M. receptaculi ZC-2 [DQ787476], $M$. taiwanensis CYW4 [KM111599], Methanofollis tationis [AF 095272], Methanoregula formicica SMSP [CP003167], Methanogenium marinum AK-1 [DQ177344], and Methanoplanus limicola DSM 2279 [CM001436]). Phylogeny was further confirmed with $m c r A$ gene sequences (M. bourgenisis MS2 [AB AB300787], M. bourgensis RC/ER [AB300785], M. bourgensis CB1 [AB300786], M. bourgensis MAB1 [KJ708788], M. bourgensis MAB2 [KJ708789], M. chikugoensis NBRC 101202 [AB 703634], M. chikugensis [AB300779], M. thermophius DSM 2624 [AF313804], and M. thermophiles [AB300783]).

\section{Nucleotide sequence accession number}

The $16 \mathrm{~S}$ rRNA and $m c r A$ gene sequences of strain KOR-2 determined in this study were deposited in the GenBank database under No. JQ973736 and KF773774.

\section{RESULTS AND DISCUSSION}

\section{Characterization of the isolated methanogen}

A new methanogen was isolated from the rumen of Holstein steers. The methanogenic enrichment culture was obtained after repeated transfer in the presence of antibiotic mixtures for 2 months. Visible colonies on solid media appeared after 2 weeks of incubation at $38^{\circ} \mathrm{C}$. Surface colonies were about 0.5 to $1.0 \mathrm{~mm}$ in diameter, yellow, circular, and convex. Only one strain, designated as KOR-2, was characterized in detail.

Table 2 shows the comparison between the phenotypic and growth characteristics of KOR-2 strain and M. bourgensis MS2 [25-27]. KOR-2 cells were irregular cocci, non-motile, 0.2 to $0.5 \mu \mathrm{m}$ in diameter, and occurred singly or in pairs (Figure 1). The growth of KOR-2 strain was observed at a temperature range of $25^{\circ} \mathrm{C}$ to $45^{\circ} \mathrm{C}$, with the fastest growth reported at $38^{\circ} \mathrm{C}$. The $\mathrm{pH}$ range suitable for its growth was 4.0 to 9.0 , and the optimum $\mathrm{pH}$ for growth was 6.8 to 7.0. KOR-2 could grow well in salinity up to $3.0 \%(\mathrm{w} / \mathrm{v})$ and the optimum $\mathrm{NaCl}$ concentration for the strain was $1.0 \%$. This range of salinity is typical for halotolerant organisms. The $\mathrm{G}+\mathrm{C}$ content of genomic DNA of KOR-2 strain was 55.5 mol\%. KOR-2 used $\mathrm{H}_{2} / \mathrm{CO}_{2}$ and sodium formate $(50 \mathrm{mM})$ but was unable to metabolize sodium acetate, methanol, trimethylamine, 2-propanol, and isobutanol as substrates for growth and methane production. The isolate was phenotypically similar to the compared strain M. bourgensis. Maestrojuán et al [26] reported that the cells of Methanoculleus are irregular cocci, 0.5 to $2.0 \mu \mathrm{m}$ in diameter, and gram-negative and occur singly or in pairs. Some species are motile. Members of the family Methanomicrobiaceae have been found in a wide variety of anaerobic 
Table 2. Comparative characteristics of KOR-2 strain isolated from the rumen of Holstein steers ${ }^{1)}$

\begin{tabular}{|c|c|c|}
\hline Characteristics & KOR-2 & MS2T \\
\hline Cell morphology & Coccoid & Coccoid \\
\hline Cell width $(\mu \mathrm{m})$ & $0.2-0.5$ & $1.0-2.0$ \\
\hline \multicolumn{3}{|l|}{ Temperature for growth $\left({ }^{\circ} \mathrm{C}\right)$} \\
\hline Range & $25-45$ & $30-49$ \\
\hline Optimum & 38 & 37 \\
\hline \multicolumn{3}{|l|}{ pH for growth } \\
\hline Range & $4.0-9.0$ & $5.5-8.0$ \\
\hline Optimum & $6.8-7.0$ & 6.7 \\
\hline \multicolumn{3}{|l|}{$\mathrm{NaCl}$ for growth range (\%) } \\
\hline Range & $0.5-3.0$ & $0-4.0$ \\
\hline Optimum & 1.0 & 1.0 \\
\hline DNA $\mathrm{G}+\mathrm{C}$ content $(\mathrm{mol} \%)^{2)}$ & $55.5(\mathrm{Tm})$ & $59(\mathrm{Bd})$ \\
\hline \multicolumn{3}{|l|}{ Substrate utilization } \\
\hline $\mathrm{H}_{2} / \mathrm{CO}_{2}$ & + & + \\
\hline Formate & + & + \\
\hline Acetate & - & - \\
\hline Methanol & - & - \\
\hline Trimethylamine & - & - \\
\hline 2-propanol & - & - \\
\hline |sobutano| & - & - \\
\hline \multicolumn{3}{|l|}{ Tolerance for antibiotics } \\
\hline Ampicillin & + & ND \\
\hline Penicillin G & + & ND \\
\hline Spectromycin & + & ND \\
\hline Kanamycin & + & ND \\
\hline Tetracycline & + & ND \\
\hline Chloramphenicol & - & ND \\
\hline
\end{tabular}

-, negative; +, positive; ND, no data available.

1) Data for strain KOR-2 are from this study, and those for strain MS2T are retrieved from Ollivier et al [25] and Maestrojuán et al [26].

${ }^{2)}$ Determined by buoyant density analysis $(\mathrm{Bd})$ and melting point analysis $\left(T_{\mathrm{m}}\right)$.

environments where methane is produced, such as the rumen of ruminant animals, anaerobic marine sediments, wetlands, and oil wells [28]. The genus Methanoculleus contains nine

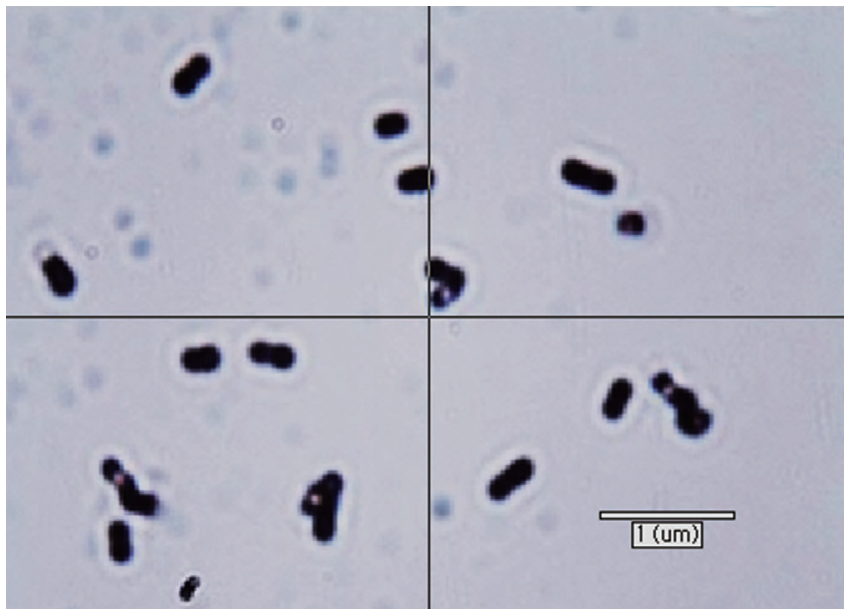

Figure 1. Phase-contrast microscopy of strain KOR-2. Bar indicates $1 \mu \mathrm{m}$. species [29]. M. bourgensis (basinym: Methanogenium bourgense), a species including the former M. olentangyi comb. nov. isolated from a tannery by-product enrichment culture inoculated with sewage sludge [25] (basinym: Methanogenium olentangyi) [30], and M. oldenburgensis [31] were described as junior heterotypic synonyms. M. hydrogenitrophicus was obtained from a wetland soil. Methanoculleus strains, including $M$. bourgensis MS2, are obligate anaerobes that produce methane from $\mathrm{H}_{2} / \mathrm{CO}_{2}$ or formate $[25,29]$. Some species also produce methane from secondary alcohols and $\mathrm{CO}_{2}$. Acetate is generally required as a carbon source, and additional growth factors may be required. Two types of methanogens, Methanosarcina sp. and Methanosaeta sp., were known to be capable of metabolizing acetate [32]. KOR-2 has typical mesophilic temperature optima, whereas other Methanoculleus species have higher or lower optima. Furthermore, some species are moderately thermophilic [33]. The $\mathrm{G}+\mathrm{C}$ content of the DNA varies between 55.5 and $62.9 \mathrm{~mol} \%$. The $\mathrm{G}+\mathrm{C}$ content value for KOR-2 was within the range for the strains belonging to the genus Methanoculleus, as reported by Ollivier et al [25]. Based on the morphology and substrate utilization, KOR-2 strain may exhibit the basic characteristics of $M$. bourgensis.

KOR-2 was able to grow in the presence of ampicillin, penicillin G, kanamycin, spectromycin, and tetracycline in the media, while the cell growth was inhibited by chloramphenicol. Sensitivity to antibiotics was reported for a limited number of species of the family Methanomicrobiaceae, M. receptaculi [34], Methanofollis aquaemaris [35], Methanofollis formosanus [36], and Methanogenium frittonii (a later heterotypic synonym of M. thermophilus) [37] and members of the genus Methanoplanus [38]. Cells are sensitive to chloramphenicol and resistant to penicillin, ampicillin, kanamycin, vancomycin, and streptomycin [29]. Methanogenium frittonii, Methanofollis aquaemaris, and Methanofollis formosanus were sensitive to tetracycline, but Methanoplanus spp. were reported to be resistant [29]. M. receptaculi, but not Methanogenium frittonii, was inhibited by erythromycin [29]. Hilpert et al [39] found that archaea were insensitive to many antibiotics that inhibit eubacteria and eukaryotes, such as those inhibiting the synthesis or cross-linkage of the peptide subunit of murein or those suppressing RNA synthesis. Thus, KOR-2 was insensitive to antibiotics used in this study except for chloramphenicol. Chloramphenicol as a protein inhibitor interferes with the cell membrane function of methanogens. However, it is unknown if this insensitivity to chloramphenicol was associated with the impermeability of the cytoplasmic membrane or inactivation of the antibiotic by the cell, rather than the absence of a particular target for the antibiotic [39].

\section{Molecular characterization}

Polymerase chain reaction of $16 \mathrm{~S}$ rRNA yielded an amplicon size of 1,350 bp. mcrA gene-based amplification was also used 


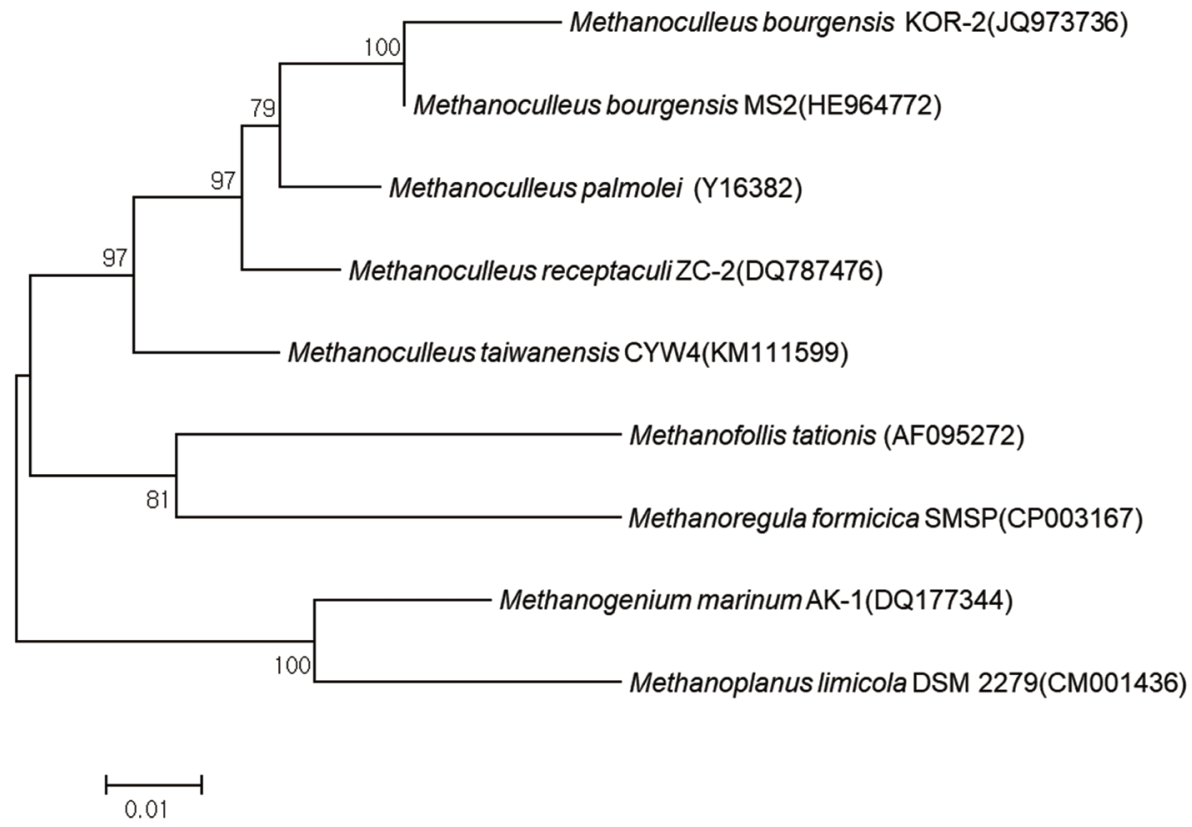

Figure 2. Phylogenetic dendrogram of $16 \mathrm{~S}$ rRNA gene sequences showing the position of the Methanoculleus bourgensis strain KOR-2 relative to other species of the genus Methanoculleus as well as selected reference sequences of methanogens. Methanofollis tationis and Methanoregula formicica were used as outgroup references. The evolutionary distances were computed using the maximum composite likelihood method [24]. Bootstrap values are shown at nodes (percentages of 500 replicates). GenBank accession numbers are indicated. A bar represents 0.01 substitutions per nucleotide position.

for identification purposes and yielded a product size of 790 bp. Comparative 16S rRNA gene sequence analysis showed that the strain was affiliated with the order Methanomicrobiales. The closest relatives of KOR-2 strain were $M$. bourgensis MS2 (98\%, sequence similarity), M. palmolei (97\%), M. receptaculi
ZC-2 (96\%), Methanofollis tationis (91\%), and Methanoplanus limicola DSM 2279 (90\%) (Figure 2). KOR-2 showed a small difference in physiological characteristics (Table 2) and $98 \%$ sequence similarity to the $16 \mathrm{~S}$ rRNA gene of $M$. bourgensis MS2 (Figure 2). The RDP Release 11 (Update 3) reported that

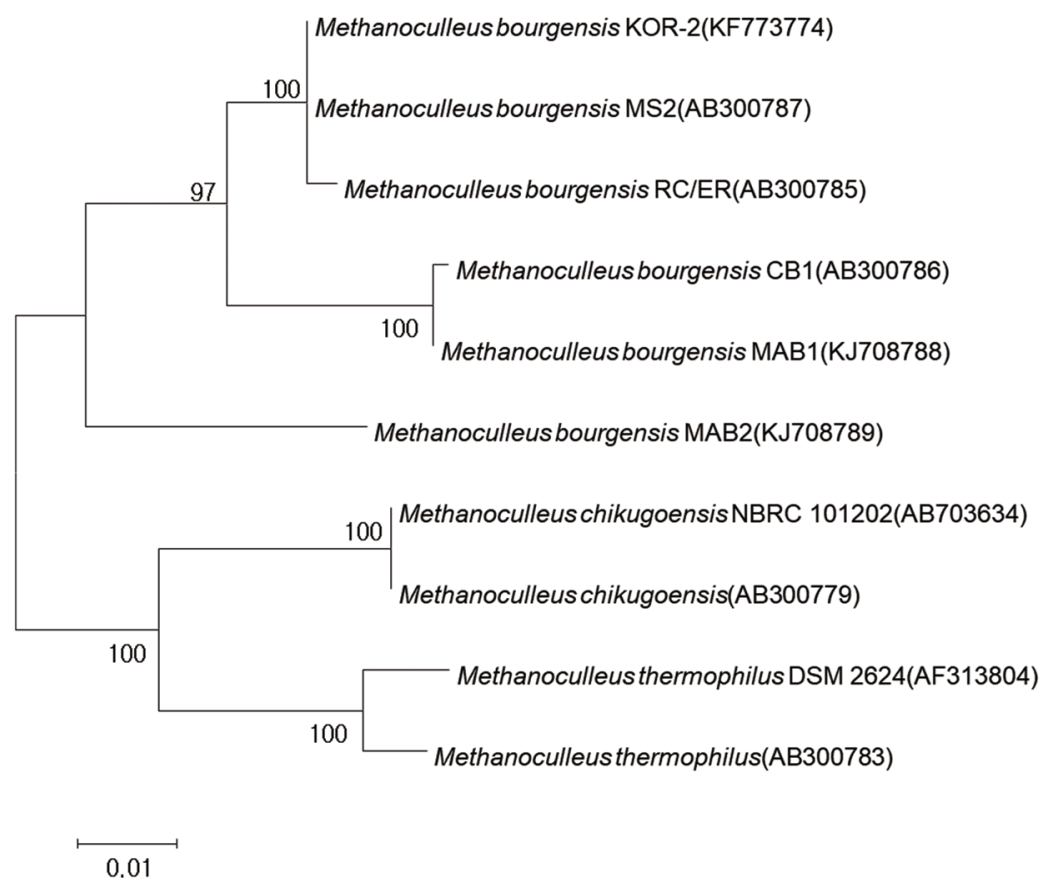

Figure 3. Phylogenetic tree of deduced mcrA gene sequences indicating the relationship between the Methanoculleus bourgensis strain KOR-2 and members of the genus Methanoculleus. GenBank accession numbers are indicated. Bootstrap values are shown at nodes (percentages of 500 replicates). A bar represents 0.01 substitutions per nucleotide position. 
a total of 8623 sequences of archaeal $16 \mathrm{~S}$ rRNA gene sequences were originated from the rumen of ruminants. About $90 \%$ of these sequences were assigned to methanogens. These sequences were classified to 10 known genera, with Methanobrevibacter being represented by $63.2 \%$ of all the sequences followed by Methanosphaera (9.8\%), Methanomicrobium (7.7\%), and Methanobacterium (1.2\%) [3]. Among the gene sequences of the rumen, the 5 sequences of Methanoculleus were identified, in which 4 sequences were recovered from isolates including one gene from M. bourgensis KOR-2. It is noted that the genus of Methanoculleus is not probably major species in the rumen. The $m c r A$ gene sequence also indicated that KOR-2 strain was a member of the order Methanomicrobiales. The closest relatives of KOR-2 strain based on the $\mathrm{mcr} A$ gene sequence were M. bourgensis MS2 (100\%) and M. chikugoensis (94\%) (Figure 3). All phylogenetic results were similar in the experiment. Luton et al [40] stated that the $m c r A$ gene sequence may be alternatively used instead of the $16 \mathrm{~S}$ rRNAbased sequence methods, demonstrating far greater diversity than that observed with $16 \mathrm{~S}$ rRNA gene sequences in the methanogen population.

On the basis of morphology, physiological characteristics, and phylogenetic analyses described above, the strain was identified as a new strain of M. bourgensis and named as KOR-2.

\section{CONFLICT OF INTEREST}

We certify that there is no conflict of interest with any financial organization regarding the material discussed in the manuscript.

\section{ACKNOWLEDGMENTS}

This work was supported by the Korea Institute of Planning and Evaluation for Technology in Food, Agriculture, Forestry and Fisheries (IPET) through the Agri-Bio industry Technology Development Program, funded by the Ministry for Agriculture, Food and Rural Affairs (MAFRA) (116086-3).

\section{REFERENCES}

1. Knapp JR, Laur GL, Vadas PA, Weiss WP, Tricarico JM. Invited review: Enteric methane in dairy cattle production: Quantifying the opportunities and impact of reducing emissions. J Dairy Sci 2014;97:3231-61.

2. Johnson KA, Johnson DE. Methane emissions from cattle. J Anim Sci 1995;73:2483-92.

3. Patra A, Park T, Kim M, Yu Z. Rumen methanogens and mitigation of methane emission by anti-methanogenic compounds and substances. J Anim Sci Biotechnol 2017;8:13.

4. Rother M, Krzycki JA. Selenocysteine, pyrrolysine, and the unique energy metabolism of methanogenic archaea. Archaea
2010;2010:453642.

5. Valle ER, Henderson G, Janssen PH, et al. Considerations in the use of fluorescence in situ hybridization (FISH) and confocal laser scanning microscopy to characterize rumen methanogens and define their spatial distributions. Can J Microbiol 2015;61:417-28.

6. Battumur U, Yoon YM, Kim CH. Isolation and characterization of a new Methanobacterium formicicum KOR-1 from an anaerobic digester using pig slurry. Asian-Australas J Anim Sci 2016;29:586-93.

7. Battumur U, Yoon YM, Bae GS, Kim CH. Isolation and characterization of new Methanosarcina mazei strains KOR-3, -4, -5 , and -6 from an anaerobic digester using pig slurry. AsianAustalas J Anim Sci 2017;30:1198-205.

8. Ziemer CJ, Sharp R, Stern MD, et al. Comparison of microbial populations in model and natural rumens using $16 \mathrm{~S}$ ribosomal RNA-targeted probes. Environ Microbiol 2000;2:632-43.

9. Garrity, GM, Lilburn TG, Cole JR, et al. Taxonomic outline of the Bacteria and Archaea. Part 1. The Archaea, phyla Crenarchaeota and Euryarchaeota [Internet]. Release 7.7. Lansing, MI, USA: Michigan State University; 2007 [cited 2007 Mar 6]. Available from: www.taxonomicoutline.org.

10. DeLong EF, Pace NR. Environmental diversity of bacteria and archaea. Syst Biol 2001;50:470-8.

11. Janssen PH, Kirs M. Structure of the archaeal community of the rumen. Appl Environ Microbiol 2008;74:3619-25.

12. Lee J-H, Kumar S, Lee G-H, et al. Methanobrevibacter boviskoreani sp. nov., isolated from the rumen of Korean native cattle. Intl J Syst Evol Microbiol 2013;63:4196-201.

13. AOAC. Official methods of analysis. 16th ed. Association of Official Analytical Chemists. Washington, DC, USA: AOAC International; 1995.

14. Van Soest PJ, Robertson JB, Lewis BA. Methods for dietary fiber, neutral detergent fiber, and nonstarch polysaccharides in relation to animal nutrition. J Dairy Sci 1991;74:3583-97.

15. Hungate RE. The anaerobic mesophilic cellulolytic bacteria. Bacteriol Rev 1950;14:1-49.

16. Balch WE, Fox GE, Magrum LJ, Woese CR, Wolfe RS. Methanogens: reevaluation of a unique biological group. Microbiol Rev 1979;43:260-96.

17. Sowers KR, Schreier HJ. Media for methanogens. In: Sowers KR, Schreier HJ, editors. Archaea - a laboratory manual methanogens. New York, USA: Cold Spring Harbor Laboratory Press; 1995. p. 459-89.

18. Sly LI, Blackall LL, Kraat PC, Tian-Shen T, Sangkhobol V. The use of second derivative plots for the determination of mol\% guanine plus cytosine of DNA by the thermal denaturation method. J Microbiol Methods 1986;5:139-56.

19. Großkopf R, Janssen PH, Liesack W. Diversity and structure of the methanogenic community in anoxic rice paddy soil microcosms as examined by cultivation and direct $16 \mathrm{~S}$ rRNA gene sequence retrieval. Appl Environ Microbiol 1998;64:960- 
9.

20. Shlimon AG, Friedrich MW, Niemann H, Ramsing NB, Finster K. Methanobacterium aarhusense sp. nov., a novel methanogen isolated from a marine sediment (Aarhus Bay, Denmark). Int J Syst Evol Micrbiol 2004;54:759-63.

21. Luton PE, Wayne JM, Sharp RJ, Riley PW. The mcrA gene as an alternative to $16 \mathrm{~S}$ rRNA in the phylogenetic analysis of methanogen populations in landfill. Microbiology 2002;148: 3521-30.

22. Hales BA, Edwards C, Ritchie DA, et al. Isolation and identification of methanogen-specific DNA from blanket bog feat by PCR amplification and sequence analysis. Appl Environ Microbiol 1996;62:668-75.

23. Simankova MV, Kotsyurbenko OR, Lueders T, et al. Isolation and characterization of new strains of methanogens from cold terrestrial habitats. Syst Appl Microbiol 2003;26:312-8.

24. Tamura K, Dudley J, Nei M, Kumar S. MEGA4: molecular evolutionary genetics analysis (MEGA) software version 4.0. Mol Biol Evol 2007;24:1596-9.

25. Ollivier BM, Mah RA, Garcia JL, Boone DR. Isolation and characterization of Methanogenium bourgense sp. nov. Int J Syst Bacteriol 1986;36:297-301.

26. Maestrojuán GM, Boone DR, Xun L, Mah RA, Zhang L. Transfer of Methanogenium bourgens, Methanogenium marisnigri, Methanogenium olentangyi, and Methanogenium thermophilicum to the genus Methanoculleus gen. nov., emendation of Methanoculleus marisnigri and Methanogenium, and description of new strains of Methanoculleus bourgense and Methanoculleus marisnigri. Int J Syst Bacteriol 1990;40:117-22.

27. Asakawa S, Nagaoka K. Methanoculleus bourgensis, Methanoculleus olentangyi and Methanoculleus oldenburgensis are subjective synonyms. Int J Syst Evol Microbiol 2003;53:15512.

28. Boone DR, Whitman WB, Koga Y. Family I. Methanomicrobiaceae Barker 1956, 15, AL emend. Balch and Wolfe in Balch, Fox, Magrum, Woese and Wolfe 1979, 286. In: Boone DR, Castenholz RW, Garrity GM, editors. Bergey's manual of systematic bacteriology, vol 1.2nd ed. The Archaea and the deeply branching and phototrophic Bacteria. New York, USA: Springer; 2001. p. 247.

29. Oren A. The family Methanomicrobiaceae. In: Rosenberg E, DeLong EF, Lory S, Stackebrandt E, Thompson F, editors. The Prokaryotes: other major lineages of bacteria and the archaea.
Berlin, Germany: Springer; 2014. p. 231-46.

30. Corder RE, Hook LA, Larkin JM, Frea JI. Isolation and characterization of two new methane-producing cocci: Methanogenium olentangyi, sp. nov., and Methanococcus deltae, sp. nov. Arch Microbiol 1983;134:28-32.

31. Blotevogel K-H, Gahl-Janßen R, Jannsen S, et al. Isolation and characterization of a novel mesophilic, fresh-water methanogen from river sediment Methanoculleus oldenburgensis sp. nov. Arch Microbiol 1991;157:54-9.

32. Ferry JG. Methanogenesis: ecology, physiology, biochemistry and genetics. New York, NY, USA: Chapman \& Hall; 1993.

33. Chong SC, Boone DR. Genus II. Methanoculleus Maestrojuán, Boone, Xun, Mah and Zhang 1990, 121VP. In: Boone DR, Castenholz RW, Garrity GM, editors. Bergey's manual of systematic bacteriology, vol 1, 2nd ed. The Archaea and the deeply branching and phototrophic Bacteria. New York, USA: Springer; 2001. p. 251-2.

34. Cheng L, Qiu TL, Li X, et al. Isolation and characterization of Methanoculleus receptaculi sp. nov. from Shengli oil field, China. FEMS Microbiol Lett 2008;285:65-71.

35. Lai MC, Chen SC. Methanofollis aquaemaris sp. nov., a methanogen isolated from an aquaculture fish pond. Int J Syst Evol Microbiol 2001;51:1873-80.

36. Wu SY, Chen SC, Lai MC. Methanofollis formosanus sp. nov., isolated from a fish pond. Int J Syst Evol Microbiol 2005;55: 837-42.

37. Harris JE, Pinn PA, Davis RP. Isolation and characterization of a novel thermophilic, freshwater methanogen. Appl Environ Microbiol 1984;48:1123-8.

38. Huber H, Huber G, Stetter KO. Genus VI. Methanoplanus Wildgruber, Thomm and Stetter 1984, 270VP (Effective publication: Wildgruber, Thomm, König, Ober, Ricchiuto and Stetter 1982, 36). In: Boone DR, Castenholz RW, Garrity GM, editors. Bergey's manual of systematic bacteriology, vol 1, 2nd ed. The Archaea and the deeply branching and phototrophic Bacteria. New York, USA: Springer; 2001. p. 259-61.

39. Hilpert R, Winter J, Hammes W, Kandler O. The sensitivity of archaebacteria to antibiotics. Zbl Bakt Mik Hyg I C 1981;2: 11-20.

40. Luton PE, Wayne JM, Sharp RJ, Riley PW. The mcrA gene as an alternative to $16 \mathrm{~S}$ rRNA in the phylogenetic analysis of methanogen populations in landfill. Microbiology 2002;148: 3521-30. 